\title{
Neonatal Myasthenia Gravis in the Infant of an Asymptomatic Thymectomized Mother
}

\author{
C. WARREN OLANOW, RUSSELL J.M. LANE, KEITH L. HULL, JR., ALLEN D. ROSES
}

\begin{abstract}
SUMMARY: $A$ case of neonatal myasthenia gravis is reported in the infant of an asymptomatic thymectomized mother with comparably elevated acetylcholine receptor (AChR) antibody titers. The mother remained asymptomatic despite elevated antibody titers while the infant became asymptomatic in association with the disappearance of the AChR antibody. It is suggested that the AChR antibody plays an essential role in the development of neonatal myasthenia gravis. It is also suggested that a thymic factor is necessary for the development of clinical symptomatology accounting for the lack of correlation between the clinical state of the mother and infant.
\end{abstract}

RÉSUMÉ: Nous décrivons l'histoire d'un nouveau-né avec myasthénie grave néonatale. Cet enfant était issu d'une mère thymectomisée mais asymptômatique chez qui le niveau d'anticorps au récepteur à l'acétylcholine $(A C h R)$ est élevé. La mère demeura asymptômatique malgré des niveaux d'anticorps élevés alors que l'enfant devint asymptômatique lorsque ses taux d'anticorps AChR déclinèrent. Nous proposons l'hypothèse selon laquelle les anticorps AChR jouent un rôle essentiel dans le développement de la myasthénie grave néonatale. Nous croyons également que la présence d'un facteur thymique est nécessaire pour le développement d'une symptômatologie clinique.

From the Department of Medicine (Neurology), Duke University Medical Center, Durham, North Carolina.

Reprint Requests to: C. Warren Olanow, M.D., Department of Medicine (Neurology), Duke University Medical Center, Durham, North Carolina 27710.

This study supported in part by clinical research grants from the Muscular Dystrophy Association of America and the Multiple Sclerosis Society.
Neonatal myasthenia gravis is a transient disorder of neuromuscular function which bears clinical, electrical and pharmacological similarity to adult myasthenia gravis. It is reported to affect $12 \%$ of the infants born to mothers with myasthenia gravis (Namba et al, 1970). Elevated acetylcholine receptor (AChR) antibody titers have been demonstrated in both infant and mother. Clinical improvement in the infant is associated with disappearance of the antibody (Keesey et al, 1977). It has therefore been presumed that neonatal myasthenia gravis is related to transplacental transfer of AChR antibody from mother to infant.

The AChR antibody has been implicated in the pathogenesis of myasthenia gravis. Circulating antibodies are found in the sera of approximately $90 \%$ of patients with myasthenia gravis (Lindstrom et al, 1976). A myasthenic syndrome can be induced in experimental animals by passive transfer of serum IGG from patients with myasthenia gravis (Toyka et al, 1975), and by monoclonal antibodies to AChR (Lennon and Lambert 1980). In vitro, AChR antibodies accelerate degradation of acetylcholine receptors in myotube tissue culture (Kao and Drachman 1977). Immunization with purified AChR induces an experimental allergic myasthenia gravis associated with the development of AChR antibodies (Patrick and Lindstrom 1973).

Recent clinical studies, however, have cast some doubt on whether the AChR antibody is the sole causative agent in the development of the clinical features of myasthenia gravis (Roses et al, 1981). It has been suggested that a thymic factor facilitates or acts in concert with the AChR antibody to produce clinical dysfunction (Olanow and Roses, 1981). The development of transient neonatal myasthenia gravis in the infant of an asymptomatic thy- mectomized mother with comparably elevated antibody titers provides support for this hypothesis.

\section{CASE REPORT}

In August, 1978, a 28 year old female delivered a 3,060 gram female infant. Ten years earlier, she had been diagnosed as suffering from Grade llb myasthenia gravis (Osserman classification) (Osserman and Genkins 1971). Anticholinesterase agents were used for eight months without significant improvement. Thereafter, a sternal splitting thymectomy was performed. Mild thymic hyperplasia was present. She improved but continued to receive small doses of anticholinesterase medications. In February, 1971, a short course of steroids was employed for deterioration following a respiratory tract infection. She has been asymptomatic and on no medication since August, 1971.

In April, 1974, she delivered her first child, a 2,890 gram infant. No problems were experienced during the pregnancy. The infant showed some difficulty with sucking and crying during the first few days of life but was not diagnosed as having neonatal myasthenia gravis. No pharmacological, electrical, or serological tests were performed.

In January, 1978, she presented with her second pregnancy. Repeat clinical examinations revealed no evidence of weakness or fatigue. Labor and delivery were uneventful. During the second day of life, the infant began to have difficulty with sucking, breathing, a weak cry and mild generalized weakness. No cranial nerve abnormalities were present. The symptoms responded dramatically to prostigmine $0.1 \mathrm{mgm} \mathrm{I.M}$. and the infant was discharged from the nursery on the fifth day. Prostigminine $1 \mathrm{mgm}$ tid was maintained for four weeks and then gradually discontinued. The infant had 


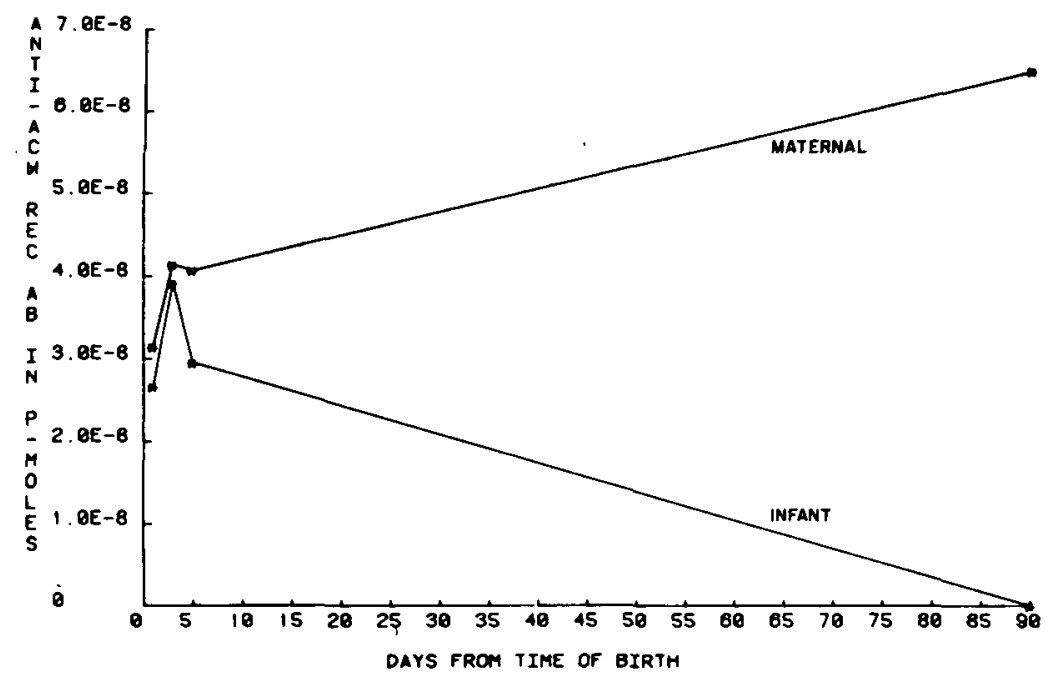

Figure 1 - Serial AChR antibody titers in an asymptomatic mother and an infant with neonatal myasthenia gravis.

no further neurological abnormality and the mother continued to be asymptomatic on no medications.

AChR antibody titers were serially assayed by a radioimmuno-assay employing human antigen as previously described (McAdams and Roses 1980). AChR antibody levels of 0.1 $\mathrm{nM}$ are diagnostic of myasthenia gravis and levels greater than $1 \mathrm{nM}$ are markedly abnormal in our laboratory. Levels were initially significantly elevated in both mother ( $3.2 \mathrm{nM})$ and infant $(2.7 \mathrm{nM})$. Antibody titers continued to be elevated in the asymptomatic mother but declined with disappearance of symptoms in the infant (Fig. 1).

\section{DISCUSSION}

We describe a case of transient neonatal myasthenia gravis in the infant of an asymptomatic thymectomized mother. AChR antibody titers were initially elevated in both. The mother remained asymptomatic without significant change in her antibody level. The infant improved in conjunction with the disappearance of the AChR antibody. Elias et al. (1979) described a case of neonatal myasthenia gravis in an asymptomatic mother in spontaneous remission. The bioactivity of the antibody, measured by accelerated receptor degradation in myotube culture, was comparable in both the affected infant and the asymptomatic mother. Observations such as these suggest that there are influences in addition to the AChR antibody which are essential for the development of clinical weakness.

Infants with neonatal myasthenia gravis can be born to mothers in all clinical stages of the disease including remission and following all current modes of therapy. There is a poor correlation between the severity of involvement in the infant and that in the mother (Namba et al, 1970).

The AChR antibody seems to be essential for the development of neonatal myasthenia gravis. In a large review, none of the mothers of patients with neonatal myasthenia had ocular myasthenia gravis (Namba et al, 1970) where AChR antibody levels are low (Lindstrom et al, 1976). The AChR antibody itself, however, does not appear to be the sole causative factor in the development of clinical symptoms. Asymptomatic infants with elevated AChR antibody titers have been reported (Lefvert et al, 1978). It is known that thymic derived T-cells can regulate virtually all immune responses (Reinherz and Schlossman 1980). We believe that an immunologically competent thymus gland determines whether the $A C h R$ antibody will result in clinical weakness. This could account for the development of neonatal myasthenia gravis in the infant of an asymptomatic thymectomized mother with comparably elevated antibody titers. This theory is supported by studies in which experimental allergic myasthenia gravis can be prevented by prior thymectomy (Penn et al, 1977; Lennon et al, 1976). Furthermore, monoclonal antibody to AChR fails to produce weakness in athymic mice while producing severe weakness in non-thymectomized Lewis rats (Lennon and Lambert 1980).

One might anticipate that more than $12 \%$ of infants born to myasthenic mothers with significantly elevated AChR antibody titers, would develop neonatal myasthenia gravis. In the review of Namba et al (1970), when one infant was affected with neonatal myasthenia gravis the next born was similarly affected in 11 of 15 cases (incidence of $73 \%$ ). This is much higher than the reported overall incidence of $12 \%$ and suggests that there is a population of mothers whose infants have a high risk of developing neonatal myasthenia gravis. Some cases may be mild and unrecognized as was perhaps the situation in the sibling of our affected patient. There may also be a relative difference in the degree of maturation of the infant thymus gland and its ability to influence the effect of the AChR antibody on the receptor.

\section{REFERENCES}

ELIAS, S.B., BUTLER, I., and APPEL, S.H. (1979) Neonatal myasthenia gravis in the infant of a myasthenic mother in remission, Ann Neurol., 6:72-75.

KAO, I. and DRACHMAN, D.B. (1977) Myasthenic immunoglobulin accelerates acetylcholine receptor degradation, Science, 196:527-529.

KEESEY, J., LINDSTROM, J., COKELY, H., and HERRMANN, C. (1977) Antiacetylcholine receptor antibody in neonatal myasthenia gravis, New Eng. J. Med., 296:55.

LEFVERT, P.K., BERGSTROM, K., MOTELL, G., et al. (1978) Determination of acetylcholine receptor antibodies in myasthenia gravis: clinical usefulness and pathogenic implications, Jr Neurol., Neurosurg. and Psych., 41:394-403. 
LENNON, V.A., and LAMBERT, E.H. (1980) Myasthenia gravis induced by monoclonal antibodies to acetylcholine receptors, Nalure, 285:238-240.

LENNON, V.A., LINDSTROM, J.M. and SEYBOLD, M.E. (1976) Experimental autoimmune myasthenia gravis: cellular and humoral immune mechanisms, $A n n . N Y$ Acad. Sci. 274:283-299.

LINDSTROM, J.M., SEYBOLD, M.E., LENNON, V.A., WHITTINGTON, S., and DUANE, V.D. (1976) Antibody to acetylcholine in myasthenia gravis, Neurol. 26:1054-1059.

McADAMS, M. and ROSES, A.D. (1970) Comparison of antigenic sources for acetylcholine receptor antibody assays in myasthenia gravis, Ann. Neurol. 8:61-66.
NAMBA, T., BROWN, S.B., and GROB, D (1970) Neonatal myasthenia gravis: report of two cases and review of the literature. Ped. 45:488-504.

OLANOW, C.W., and ROSES, A.D. (1981) The pathogenesis of myasthenia gravis: A hypothesis. Medical Hypothesis. 7:957-968.

OSSERMAN, K.E. and GENKINS, G. (1971) Studies in myasthenia gravis: review of a 20 year experience in over 1200 patients, $M t$. Sinai J. Med. 38:497-537.

PATRICK, J. and LINDSTROM, J.M. (1973) Autoimmune response to acetylcholine receptor. Science, 180:871-872.

PENN, A.S., LOVELACE, R.E., LANG, D.J., TOUFEXIS, G., and BROCKBANK, $\mathrm{K}$. (1977) Experimental myasthenia gravis in neonatally thymectomized rabbits, Neuro$\log y$ (Minneap) 27:365.

REINHERZ, E.L. and SCHLOSSMAN, S.F. (1980) The differentiation and function of human T lymphocytes Cell, 19:821-827.

ROSES, A.D., OLANOW, C.W., McADAMS, M., and LANE, R.J.M. (1981) There is no direct correlation between the serum antiacetylcholine receptor antibody levels and the clinical status of individual patients with myasthenia gravis, Neurol., 31:220-224, 1981.

TOYKA, K.V., DRACHMAN, D.B., PESTRONK, A., KAO, I. (1975) Myasthenia gravis: passive transfer from man to mouse, Science, 190:397-399. 